\title{
非水溶性凝固球の水中での融解熱伝達*
}

\author{
田中雄 太*1, 菱田誠*2, 田中 学*2
}

\section{Heat Transfer of Melting Immiscible Sphere in Water}

\author{
Yuta TANAKA, Makoto HISHIDA*3 and Gaku TANAKA \\ ${ }^{* 3}$ Department of Electronics and Mechanical Engineering, Chiba University, \\ 1-33 Yayoi-cho, Inage-ku, Chiba-shi, Chiba, 263-8522 Japan
}

\begin{abstract}
This paper deals with experimental and analytical heat transfer study of nonadecane spheres melting in natural convection of water. Experimental local and average heat transfer coefficients were obtained by analyzing the photo images of the shape change of nonadecane spheres. The relevant dimensionless parameters were varied in the ranges of $1.8 \times 10^{7} \leq \mathrm{Gr}_{n} \cdot \operatorname{Pr}_{n} \leq 1.8 \times 10^{8}$ and $0.04 \leq C_{n} \Delta T / L_{n} \leq 0.16$. We found: (1) Melting nonadecane sphere was covered with thin nonadecane liquid film flowing upwards along the sphere to make a liquid cap on the top. The cap regularly repeated formation and splitting off. (2) The experimental average Nusselt number was correlated by $\mathrm{Nu}=0.151\left(\mathrm{Gr}_{n} \cdot \operatorname{Pr}_{n}\right)^{0.257}\left(C_{n} \Delta T / L_{n}\right)^{0.117}$ that was in good agreement with analytical one. ( 3 ) On the lower hemisphere experimental heat transfer coefficients were slightly higher than analytical ones and on the upper hemisphere the experimental heat transfer coefficients were slightly lower than analytical ones.
\end{abstract}

Key Words: Melting Heat Transfer, Nonadecane Sphere, Natural Convection of Water

\section{1. 粕 言}

物質の融解を伴う熱伝達は工業的な応用範井の広い 伝熱現象であり多くの研究がなされている(1). その中 で最も基本的な形状を持った平板，円柱及び球が融解 する際の熱伝達については, 氷層, 氷円柱及び氷球が 水の自然対流によって融解する際の熱伝達 ${ }^{(1-4)}$, 水層, 水円柱が海水中で融解する際の熱伝達(1,5)等について の研究が行われている. しかしながら，これらはい ずれも融解した液体と周囲液体とが同じ水であった り融解した水が周囲流体である塩水中に容易に融解 したりする場合の熱伝達に関する研究である.

近年, 夜間電力を利用した冷熱貯蔵等の観点から, 潜熱蓄熱に関する研究(6,7)が盛んに行われているが, 潜熱蓄熱の分野では，パラフィン系オイル等のように 非水溶性物質が蓄熱材の候補物質の一つとして上げら れている. パラフィンが水中で融解すると，その液は 水に溶解しないため, 球や円柱表面上に薄い液膜を形 成する. パラフィンの密度は通常水より小さいため, パラフィン液の薄膜は球や円柱表面に沿って浮上する. このように，蓄熱材と周冊液体とが互いに溶解しない 場合の融解熱伝達については、山田 ${ }^{(8)} ら か ゙$ 水円柱を植

* 原稿受付 2005 年 4 月 18 日.

*1 千葉大学大学院自然科学研究科( $-263-8522$ 千葉市稲毛区 弥生町 1-33).

*2 正員, 千葉大学工学部.

E-mail : hishida@ faculty.chiba-u.jp
物油中で融解する実験を行い，円柱周りの局所熱伝達 率と平均熱伝達率等を測定している. この場合水の密 度は植物油の密度より大きいため，融解によってでき た水の薄膜は氷円柱の表面に沿って流下寸る. また山 田等は二重境界層モデルによる解析を行い実験值と比 較を行っているが，局所熱伝達率や平均熱伝達率は二 重境界層モデルにより正確に予測できない場合もある ようである.

そこで, 本研究ではパラフィン系物質の一種であ るノナデカンの凝固球を静水中で融解させる実験を行 い，局所熱伝達率や平均熱伝達率を測定するとともに, 平均熱伝達率の実験式を作成した. また, 実験と平行 して解析も行い, 実験結果と比較検討した。

\section{2 主な記号}

$\begin{array}{llll}a & : \text { 試験球の長径 } & {[\mathrm{m}]} \\ b & : \text { 試験球の短径 } & {[\mathrm{m}]} \\ C & : \text { 比熱 } & {[\mathrm{J} /(\mathrm{kg} \cdot \mathrm{K})]} \\ d & : \text { 試験球の直径 } & {[\mathrm{m}]} \\ \mathrm{Gr} & : \text { グラスホフ数 } & \\ g & : \text { 重力加速度 } & {\left[\mathrm{m} / \mathrm{s}^{2}\right]} \\ h & : \text { 平均熱伝達率 } & {\left[\mathrm{W} /\left(\mathrm{m}^{2} \cdot \mathrm{K}\right)\right]} \\ h_{\omega} & : \text { 局所熱伝達率 } & {\left[\mathrm{W} /\left(\mathrm{m}^{2} \cdot \mathrm{K}\right)\right]} \\ L & : \text { 融解潜熱 } & {[\mathrm{J} / \mathrm{kg}]} \\ m & : \text { 試験球の質量 } & {[\mathrm{kg}]}\end{array}$




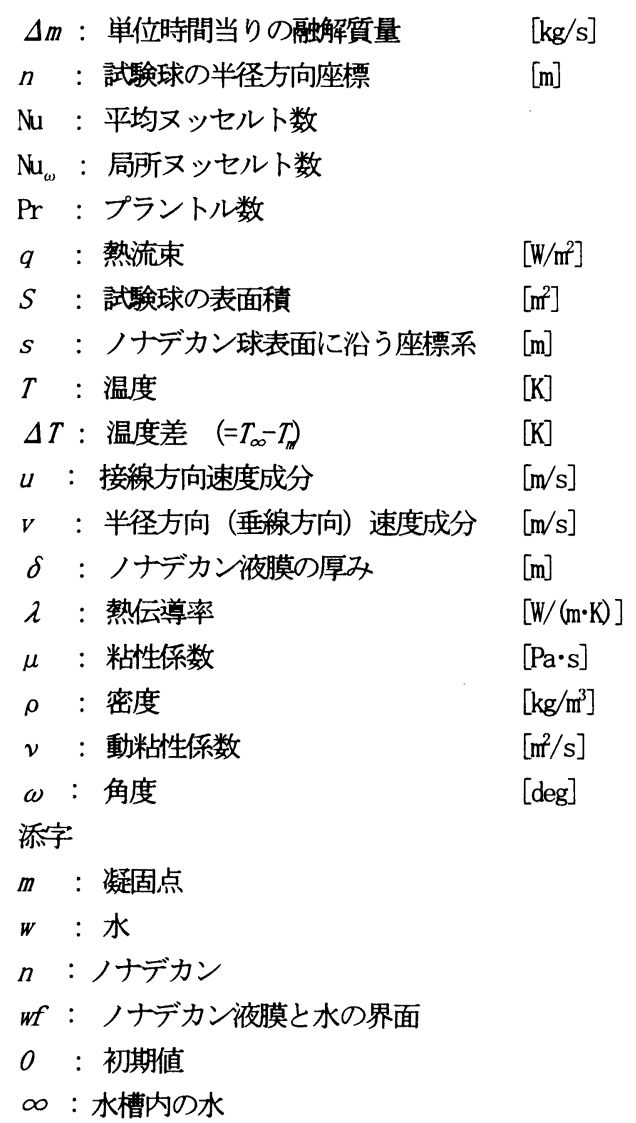

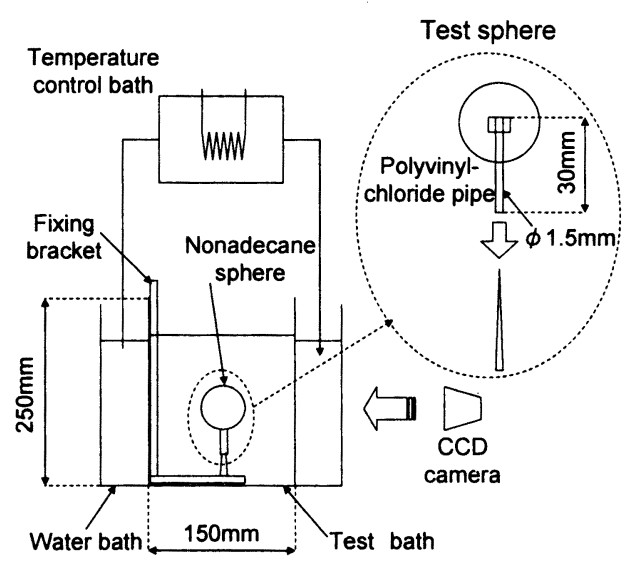

Fig.1 Experimental setup

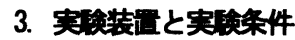

実験装置を図 1 に示す，実験装置は主に試験容器， 圾験球固定器具，圾験球，水槽，調温部，測定部等か らなる. 試験容器は, $150 \times 150 \times 250 \mathrm{~mm}$ のアクリル製 矩形容器でこの中に水が満たされる. 固定器具で保持
Table.1 Physical property of nonadecane

\begin{tabular}{|ll|l|}
\hline Melting temperature & {$[\mathrm{C}]$} & 31.3 \\
\hline Latent heat ${ }^{(10)}$ & {$[\mathrm{kJ} / \mathrm{kg}]$} & 177.4 \\
\hline Density (at $\left.31.3^{\circ} \mathrm{C}\right)$ & {$\left[\mathrm{kg} / \mathrm{m}^{3}\right]$} & 775 \\
\hline Dynamic viscosity (at $\left.35^{\circ} \mathrm{C}\right)$ & {$\left[\mathrm{m}^{2} / \mathrm{s}\right]$} & $5.68 \times 10^{-6}$ \\
\hline Thermal conductivity $\quad[\mathrm{W} / \mathrm{m} \mathrm{K}]$ & 0.18 \\
\hline Specific heat ${ }^{(10)}$ & {$[\mathrm{J} /(\mathrm{kg} \cdot \mathrm{K})]$} & 2200 \\
\hline
\end{tabular}

された試験球を試験容器内に設置し融解実験を行う. 試験容器全体は水槽内に設置されており, 恒温槽で一 定温度に保持された水を水槽内に循環させることによ り, 試験容器内の水温を一定に保つ. 試験容器内の水 温を $\mathrm{K}$ 型熱電対で測定し，実験中変化しないことを確 認した. 試験球はパラフィン系オイルのノナデカンで ある.ノナデカン球はステンレス製の中空半球を二つ 組み合わせ，合わせ面に空けた小孔よりノナデカン液 を注入し冷却して凝固させて作成した. その際, 塩化 ビニール製の細管 $(1.5 \mathrm{~mm} \phi \times 30 \mathrm{~mm})$ をノナデカン球 の下部に取り付けて一緒に凝固させた. この細管を試 験球固定器具先端の支持針に取り付けることにより, 試験球を固定する. 試験球は恒温槽内で初期温度 $\left(30.0^{\circ} \mathrm{C}\right)$ に保持した後, 訌験容器内に設置し融解する. 試験球の初期温度を融点 $\left(T m=31.3^{\circ} \mathrm{C}\right)$ に可能な限り 近づけることにより融解熱量に比べて顕熱量を無視で きるほど小さくした.

表 1 にノナデカンの物性值を示寸. 密度は比重計で, 動粘度はキャノンフェスケ粘度計でそれぞれ測定した. 熱伝導率は, 非定常線熱源法けにより測定した. 融解 潜熱と比熱の值は文献(10)に記載されている值を用いた。 本実験では, 融解の進行とともに変化する試験球 形状を ஹ カメラで撮影し，画像解析することにより， ノナデカン球周りの局所熱伝達率及び平均熱伝達率を 求めた.

試験球の初期直径 $d_{0}$ を 16，22.5，28，34m の 4段階, 水槽内の水の温度と融点の温度差 $\Delta T\left(=T_{\infty}-T_{m}\right)$ を 3.2 , $5.7,8.2,13.2^{\circ} \mathrm{C} の 4$ 段階に変化させて実験を行った.

\section{4. 实竢データの解析方法}

ஹ カメラで撮影した画像を解析することにより， 圾験球の質量及び表面積の時間変化を求めた. 単位時 間当たりの質量减少量と融解潜熱から試呀球への流入 熱量を求め, その值を表面積で除することにより熱流 束を求めた.

撮影画像を中心角が $10^{\circ}$ の小区間 (扇形) に区切 $\eta$, 実験開始後の時刻 $t$ における小区間の面積と円弧 
の長さを求めた。試験球は軸対象形状であるという仮 定の下に，それぞれの扇形部分の質量 $m(\omega)$ と表面積 $S(\omega)$ の時間变化を求めた. 質量 $m(\omega)$ と時刻 $t$ の 関係加単位時間当りの質量变化 $\Delta m(\omega)$ を求め, 次 式より試験球表面の熱流束分布を求めた。

$$
q(\omega)=(L \cdot \Delta m(\omega)) / S(\omega)
$$

このような画像解析法による質量計測の精度を確 認するため, 画像解析によって求めた訊験球の質量と 電子天秤によって測定した質量とを比較した. その結 果を図 2 に示寸. 図加分かるように画像解析によっ て求めた球の質量と, 電子天秤によって求めた質量と の差は土5\%以内である．縦軸に含まれる $m_{0}$ は試験球 の初期質量である。

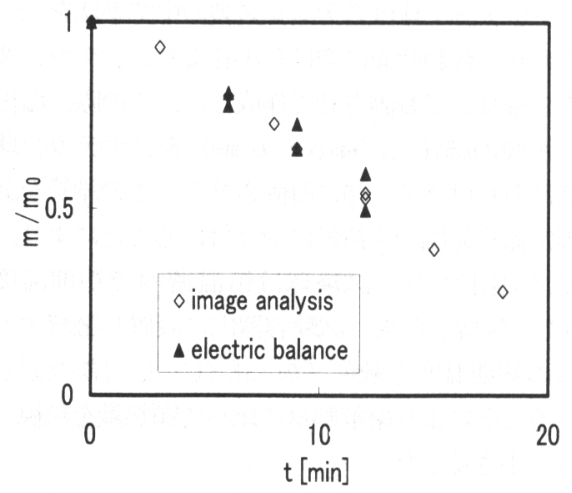

Fig.2 Comparison of measuring method for mass of test sphere between image analysis and electric balance
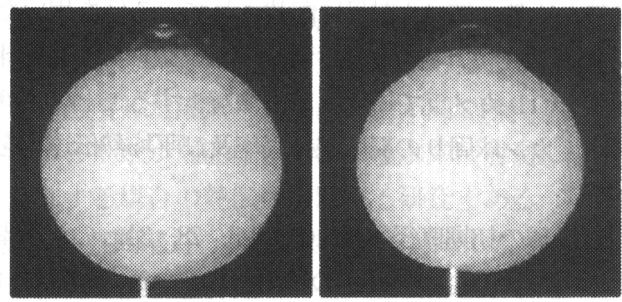

(a) $t=0 \mathrm{~min}(a b=1.0)$

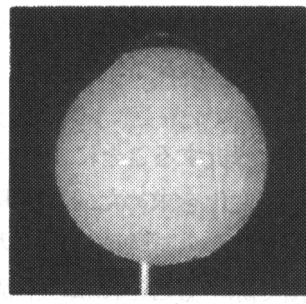

(b) $t=0.5 \min (a b=0.98)$

(c) $t=1.0 \mathrm{~min}(a b=0.93)$

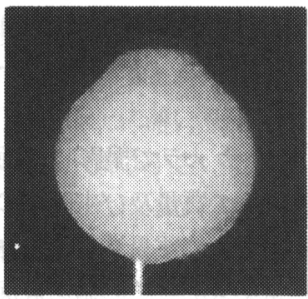

(d) $t=1.5 \mathrm{~min}(a b=0.89)$

Fig.3 Melting nonadecane sphere $\left(d /=34 \mathrm{~mm}, \Delta T=13.2^{\circ} \mathrm{C}\right)$
なお，(1)式によって熱流束を求めるためには，試 験球に流入寸る熱の全てがノナデカンの融解に使われ る必要がある, 本実験では, 試験球の初期温度は $30^{\circ} \mathrm{C}$ であり, 融点に比べて $1.3^{\circ} \mathrm{C}$ 低い，そこで, 予備 検討により, ノナデカン球内の非定常温度分布の解析 を行い, 試験球の温度上昇に使用される熱量(顕熱)を 求めた. その結果, 顕熱の最大值は融解の初期段皆に 現われるが，その值は最大でもノナデカンの融解に使 用される熱の10\%以下であった。

局所熱伝達率, 平均熱伝達率, 局所ヌッセルト数, 平均ヌッセルト数は次式によって定義した.

$$
\begin{aligned}
& h_{\omega}=\frac{q(\omega)}{\Delta T}, \quad h=\frac{\int q(\omega) d S}{\Delta T \int d S} \\
& \mathrm{Nu}_{\omega}=\frac{h_{\omega} d_{0}}{\lambda_{\infty}}, \quad \mathrm{Nu}=\frac{h d_{0}}{\lambda_{\infty}}
\end{aligned}
$$

ここで, $\Delta T\left(=T_{\infty}-T_{m}\right)$ は水槽内の水の温度とノナ デカンの凝固温度との差である.

ノナデカン液を基淮としたグラスホフ数 $\mathrm{Gr}_{\mathrm{n}}$ を次式 によって定義した

$$
\mathrm{Gr}_{\mathrm{n}}=\frac{g d_{0}^{3}\left(\rho_{\infty}-\rho_{n}\right)}{v_{n}{ }^{2}}
$$

本実験では, 試験球の初期直径を変えて $\mathrm{Gr}_{\mathrm{n}}$ を変化 させ, 温度差 $\Delta T$ を変えて無次元数 $\left(C_{n} \Delta T L_{n}\right)$ を変化さ せた. 本実験範囲は $1.8 \times 10^{7} \leqq \mathrm{Gr}_{n} \leqq 1.8 \times 10^{8}, 0.04 \leqq$ $C_{n} \Delta T L_{n} \leqq 0.16$ である. なお, 本実験範用では, ノナデ カン液膜の周囲に発生する水の自然対流は層流である.

\section{5. ノナテカン球の融解の様子}

図3に融解による試験球の形状変化の様子を示寸. $d_{0}=34 \mathrm{~mm}, \Delta T=13.2^{\circ} \mathrm{C}$ の場合について示してある.， ナデカン試験球を水中で融解させると, 試験球は融解 したノナデカン液の薄膜によって覆われる.ノナデカ ンは非水溶性であり, また, 密度は周囲の水よりも小 さいため, 融解によって形成される液膜は浮力により 試験球表面に沿って上昇し試験球上部に液塊を形成す る.この液塊はある程度の大きさになると分離して上 昇寸る. 本実験条件下における液塊の離脱周期は毎分 1.73〜17. 4 回であった. 写真から分かるように, 試験 球上部と圾験球下部の融解が遅く, 側面の融解が速い. そのため, 融解の進行とともに, 試験球の形状は洋ナ シ形に変化する. 試験球上部においてはノナデカン液 塊が熱抵抗になっているために融解速度が遅く, 下部 においては水の自然対流熱伝達率が小さいため融解が 遅くなっているものと考えられる. 
以下に示す実験結果は, 試験球の等価直径が初期 直径の 1 0.95, 試験球の短径 (a) と長径 $(\mathrm{b})$ の比が $1 \sim$ 0.90 の範囲の結果である. すなわち, 本研究では, ノナデカン球がほぼ真球形状を維持していると考えら れる融解の初期段階における熱伝達について調べる. なお，ここで等価直径とはノナデカン試験球の撮影画 像の面積と等しい面積を持つ円の直径である.

図 4 にノナデカン液塊の付着角（ $\phi ）$ と試験球の 初期值径との関係を示す. 液塊の付着角は試験球の初 期直径の増加とともに, 減少している. また, 付着角 は温度差 $\Delta T$ を変えてもほとえど変化しなかった。

\section{6. 理奥析による慗伝達の検討}

6. 1 解析モデル 上述のように，ノナデカン球 を水中で融解させると, 融解したノナデカンはノナデ カン凝固球表面に薄い液膜を形成する. 試験球上部に 形成される液塊は成長と分離を繰り返すが, 試験球周 りに形成される液膜は, 液塊の形成・分離によってほ とんど影響を受けず時間的にほぼ一定の厚さを保持し ていると考えられる. したがって本解析では, 図5に 示すようにノナデカン球はノナデカン液膜の定常流に

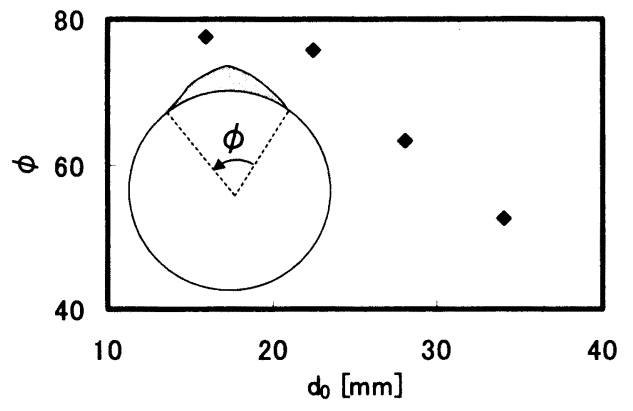

Fig.4Sticking angle of nonadecane liquid cap

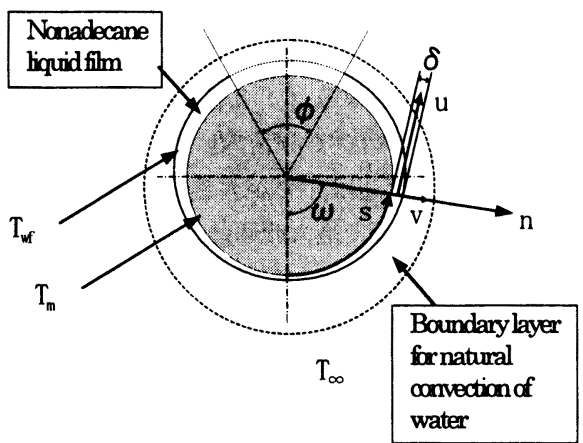

Fig.5 Nonadecane sphere melting in natural convection of water
よって覆われ，その外側には水の定常自然対流が 生じているという解析モデルを考えた.

ノナデカン液膜内の速度分布と温度分布及び夜 膜の厚みを求める境界層方程式 (11), 及び, 境界条 件として下式が得られる.

液膜内の運動量保存の式

$$
\rho_{n} u \frac{\partial u}{\partial s}+\rho_{n} v \frac{\partial u}{\partial n}=\mu_{n} \frac{\partial^{2} u}{\partial n^{2}}-g\left(\rho_{n}-\rho_{\infty}\right) \sin \omega
$$

液膜内におけるエネルギ一保存の式

$$
\rho_{n} C_{n} u \frac{\partial T}{\partial s}+\rho_{n} C_{n} v \frac{\partial T}{\partial n}=\lambda_{n} \frac{\partial^{2} T}{\partial n^{2}}
$$

境界条件

$$
\begin{gathered}
n=0 \text { で } u=0, \quad v=0, \quad T=T_{m} \\
\lambda_{n}\left(\frac{d T}{d n}\right)_{n=0}=\frac{\eta_{\infty}^{\prime}-T_{m}}{\frac{1}{h_{\omega w}}+\frac{\delta}{\lambda_{n}}}
\end{gathered}
$$

ここで， $h_{\omega w}$ はノナデカン液膜表面の水の自然対流熱 伝達率であり， $\delta$ はノナデカン液膜の厚みである.

また，ノナデカンの粘性係数は水の粘性係数の 5 倍程度の大きさであるので，ノナデカン液膜表面にお いて以下の境界条件を与えた。

$$
n=\delta \text { で } \mu_{n} \frac{\partial u}{\partial n}=0
$$

ノナデカン液膜は非常に薄く, またその上昇速度も遅 いため, 運動量保存式とエネルギ一保存式において, 左辺の対流項を無視して差し支えない.この仮定の下 に, 運動量, エネルギーの式を解くと, 液膜内の速度 分布, 温度分布として次式が得られる.

$$
\begin{aligned}
& u=\frac{g\left(\rho_{\infty}-\rho_{n}\right) \sin \omega}{2 \mu_{n}} n(2 \delta-n) \\
& T=\frac{\left(T_{\infty}-T_{m}\right)}{\frac{\lambda_{n}}{h_{\omega w}}+\delta} n+T_{m}
\end{aligned}
$$

ここで, 角度が 0 〜 $\omega$ 間のノナデカン球表面に流 入した熱は全て融解に使われたと考えて良いので, エネルギー保存則より次式が成立する.

$L \rho_{n} \int_{0}^{\delta} 2 \pi\left(\frac{d_{0}}{2}+n\right) \cdot \sin \omega \cdot u d n=\lambda_{n} \int_{0}^{\omega} 2 \pi\left(\frac{d_{0}}{2}\right)^{2} \sin \omega^{\prime}\left(\frac{\partial T}{\partial n}\right)_{n=0} d \omega^{\prime}$

(9) (10)式を上式(11)に代入し， $d_{0} \gg \delta$ 関係を用い ると次式が得られる.

$\frac{L \rho_{n} g\left(\rho_{\infty}-\rho_{n}\right) \delta^{3} \sin ^{2} \omega}{3 \mu_{n}}=\lambda_{n}\left(\frac{d_{0}}{2}\right)\left(T_{\infty}-T_{m}\right) \int_{0}^{\omega} \sin \omega^{\prime} \frac{1}{\frac{\lambda_{n}}{h_{a w}}+\delta} d \omega^{\prime}$ 
上式を $\omega て ゙$ 微分すると次式が得られる.

$\frac{d \delta}{d \omega}=\frac{v_{n} d_{0}\left(T_{\infty}-T_{m}\right)}{2 \operatorname{Lg}\left(\rho_{\infty}-\rho_{n}\right) \delta^{2} \sin \omega} \cdot \frac{1}{\frac{1}{n_{\omega w}}-\frac{\delta}{\lambda_{n}}}-\frac{2}{3} \delta \frac{1}{\tan \omega}$

式(13)を無次元表示すると次式となる.

$\frac{d\left(\delta / d_{0}\right)}{d \omega}=\frac{1}{2} \cdot \frac{C_{n} \Delta T / L_{n}}{G r_{n} P r_{n}} \cdot \frac{1}{\sin \omega} \cdot \frac{1}{\frac{1}{N u_{a w}}+1}\left(\frac{\delta}{d_{0}}\right)^{3}-\frac{2}{3} \cdot \frac{1}{\tan \omega}\left(\frac{\delta}{d_{0}}\right)$

上式を式(15)の境界条件の下でルンゲ・クッタ法によ り解き, 液膜厚さ $(\delta / d)$ を求めた.

$$
\omega=0 \text { で } \frac{d\left(\delta / d_{0}\right)}{d \omega}=0
$$

ここで, $\mathrm{Nu}_{\omega \text { }}$ はノナデカン液膜表面における水の自 然対流による局所ヌッセルト数である. ノナデカン液 膜の厚さは非常に薄いので, $\mathrm{Nu}_{\text {ow }}$ の值には固体球表面 周りの自然対流熱伝達率の值を使用できると考えられ る. 文献 ${ }^{(121)}$ によれば球の自然対流熱伝達率は次式で 表される.

$$
\mathrm{Nu}_{\omega w}=\text { 関数 }\left[\omega, \mathrm{Pr}_{\infty}\right] \times\left(\mathrm{Gr}_{\infty} \cdot \mathrm{Pr}_{\infty}\right)^{1 / 4}
$$

図6に固体球周りの層流局所熱伝達率分布を示寸.

F.H. Garner と J.M.Hoffman ${ }^{(2)}$ 及び F.A.M. Schenkels と J. Schenk ${ }^{(1)}$ が測定した固体球周りの層流局所熱伝達率 を $\mathrm{Nu}_{\omega} / \mathrm{Nu}_{\omega, \max }$ と $\omega$ との関係で整理した結果であり, 彼 らの測定値の平均値を示してある.

図6より平均ヌッセルト数 $\mathrm{Nu}$, と最大局所ヌッセル 卜数 $\mathrm{Nu}_{\omega_{\text {max }}}$ との間には次式の関係のあることが分る.

$$
\mathrm{Nu}_{u}=0.719 \cdot \mathrm{Nu}_{\text {omax }}
$$

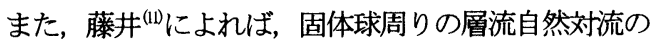
平均ヌッセルト数は次式で整理できる.

$$
\mathrm{Nu}_{\mathrm{w}}=0.527 \cdot\left(\mathrm{Gr}_{w} \cdot \mathrm{Pr}_{\mathrm{w}}\right)^{1 / 4}
$$

式(17), (18) と図6より, 固体球周りの局所ヌッセル 卜数を求めることができる.

本研究範囲においては, $\mathrm{Gr}_{\mathrm{n}} \cdot \mathrm{Pr}_{\mathrm{n}}$ と $C_{n} \Delta T / L_{n}$ の值を決 めると $\mathrm{Gr}_{w}$ と $\operatorname{Pr}_{w}$ の値は一義的に定まってしまう．した がって, 式(14) と境界条件 (式(15)）より, 液膜の無 次元厚みは次式のような関数で表される.

$$
\delta / d_{0}=\text { 関数 }\left[\left(\mathrm{Gr}_{\mathrm{n}} \cdot \mathrm{Pr}_{\mathrm{n}}\right),\left(C_{n} \Delta T / L_{n}\right), \omega\right]
$$

試験球周りの局所ヌッセルト数は下式(20)に $\delta / d_{0}$ の值を代入して求めた.

$$
\mathrm{Nu}_{\omega}=\frac{1}{\frac{1}{h_{a w}}+\frac{\delta}{\lambda_{n}}} \cdot \frac{d_{0}}{\lambda_{w}}=\frac{1}{\left(\frac{\delta}{d_{0}}\right) \frac{\lambda_{w}}{\lambda_{n}}+\frac{1}{N u_{\omega w}}}
$$

式(17)〜 (20)より局所ヌッセルト数は下式のような 関数で表されると考えられる.

$$
\mathrm{Nu}_{\omega}=\text { 関数 }\left[\left(\mathrm{Gr}_{\mathrm{n}} \cdot \mathrm{Pr}_{n}\right),\left(C_{n} \Delta T / L_{n}\right), \omega\right]
$$

平均ヌッセルト数は式(22)により求められる.

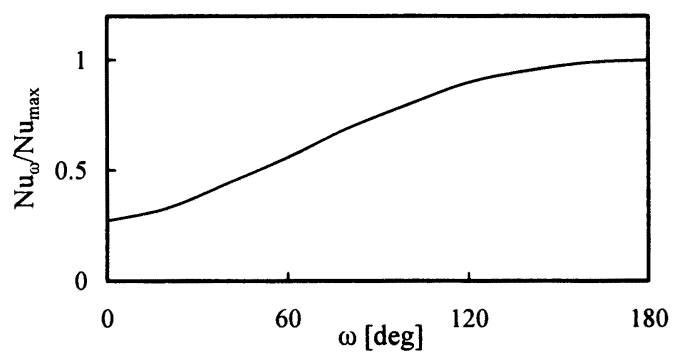

Fig.6Local Nusselt number around a round sphere

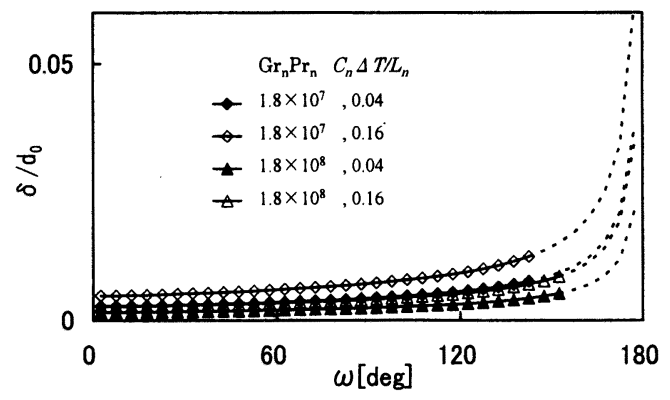

Fig.7 Calculated thickness of nonadecane hiquid film

$$
\mathrm{Nu}=\frac{1}{2} \int_{0}^{\pi-\phi / 2} N u_{\omega} \sin \omega d \omega
$$

式(22)の積分に当っては, 図4に示すへキサデカン 液塊の付着角の範囲（ $\phi ）$ は除いた。

本実験範用においては，液塊の付着角の範井 $(\phi)$ は, $\mathrm{Gr}_{\mathrm{n}} \cdot \mathrm{Pr}_{\mathrm{n}}$ と $C_{n} \Delta T / L_{n}$ の值によって一義的に定まって しまうので, 式(21), (22)より平均ヌッセルト数は次式 のような関数で表されると考えられる.

$$
\mathrm{Nu}=\text { 関数 }\left[\left(G_{n} \cdot \operatorname{Pr}_{n}\right),\left(C_{n} \Delta T / L_{n}\right)\right]
$$

6.2.ノナデカン液膜の厚みの解析結果図 7 にノ ナデカン液膜の厚さの解析結果を示す. 点線はノナデ カン液塊によって覆われている範用であり, 本解析結 果を適用できない範用である. 図から分かるように, 液膜厚さは $\omega=0 \sim 150^{\circ}$ の範用では徐々に増加するが， $150^{\circ}$ 以上（液塊で覆われる辺り）になると急激に增 加する. また, 液膜の厚み $\left(\delta / d_{0}\right)$ は $C_{n} \Delta T L_{n}$ が大き い程厚く, $\mathrm{Gr}_{\mathrm{n}} \cdot \mathrm{Pr}_{\mathrm{n}}$ が小さいほど厚い.

液膜の接線方向流速は， $\omega$ が大きくなるほど速く なる. また, 液膜表面で最大流速となり, その值は試 験球の直径及ひ試験球と水との温度差が大きい程大き くなる. しかしながら, 本解析条件下では, 最大流速 は約 $1 \mathrm{~cm} / \mathrm{s}$ 以下と小さな值であった. 液膜厚さと流 速の解析結果から液膜内を対流で輸送される熱量と, 液膜をよぎって試験球表面に達する熱量の実測值とを 比較したところ, 前者は後者の約 $3 \%$ 以下であった. 
6.3. 局所熟云達率の解析結果と実験結果 図 8 と 図 9 に局所ヌッセルト数分布の実験值と解析值の比 較を示す. 図 8 には $\mathrm{Gr}_{\mathrm{n}} \cdot \operatorname{Pr}_{\mathrm{n}}=1.8 \times 10^{8}$ で $C_{n} \Delta T L_{n}=$ $0.04 \sim 0.16$ の場合の局所ヌッセルト数分布の比較を示 し, 図9には $C_{n} \Delta T L_{n}=0.16 て ゙, \mathrm{Gr}_{\mathrm{n}} \cdot \operatorname{Pr}_{\mathrm{n}}=1.8 \times 10^{7} \sim$ $1.8 \times 10^{8}$ の場合の比較を示す.

いずれの場合も, 試験球下部では実験値の方が解 析值より大きく, 圾験球上部では実験值の方が解析值 より小さな值となっている.

図 10 に, 水温と試験球表面温度（ノノナデカンの融 点に等しい) との差 $\Delta T\left(=T_{\infty}-T_{m}\right)$ に占めるノナデ カン液膜内での温度降下 $\Delta T_{n}\left(=T_{w}-T_{m}: T_{w f}\right.$ はノナデカ ン夜膜表面の温度) の割合 $\left(\Delta T_{n} / \Delta T\right)$ を示す。

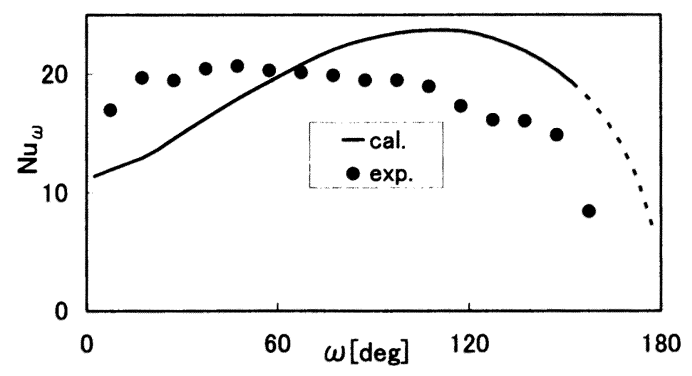

(a) $\mathrm{Gr}_{\mathrm{n}} \mathrm{Pr}_{\mathrm{n}}=1.8 \times 10^{8}, C_{n} \Delta T L_{n}=0.16$

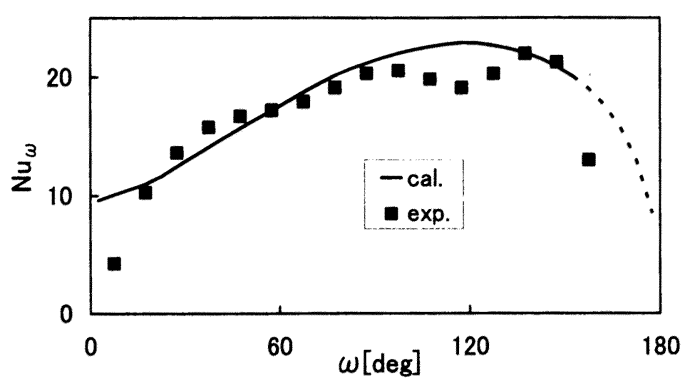

(b) $\mathrm{Gm}_{n} \mathrm{Pr}_{\mathrm{n}}=1.8 \times 10^{8}, C_{n} \Delta T / L_{n}=0.07$

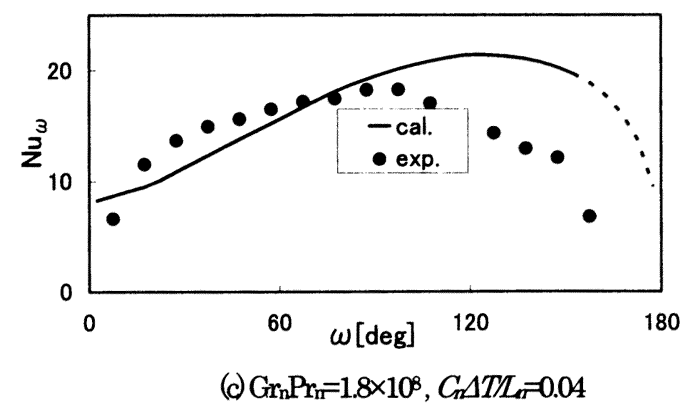

Fig.8Comparison of experimental local Nusselt number with theoretical one $\left(\mathrm{Gr}_{n} \mathrm{Pr}_{\mathrm{n}}=1.8 \times 10^{8}, C_{n} \Delta T L_{n}=0.04-0.16\right)$

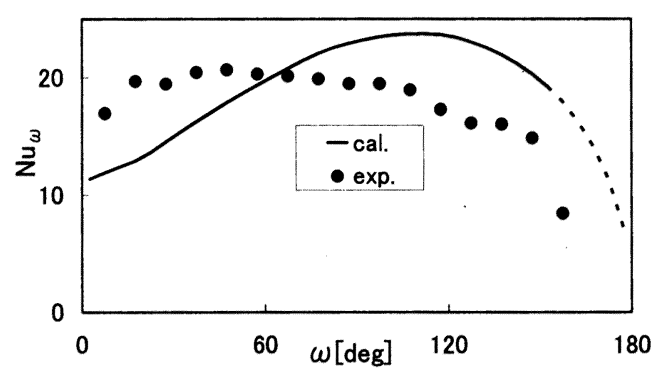

(a) $\mathrm{Gr}_{n} \mathrm{Pr}_{\mathrm{n}}=1.8 \times 10^{8}, C_{n} \Delta T L_{n}=0.16$

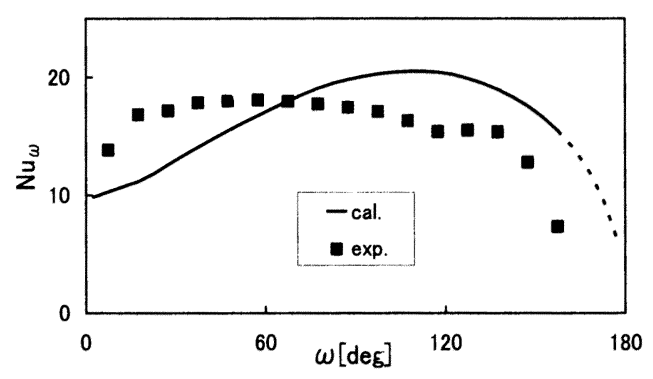

(b) $\mathrm{Gr}_{n} \mathrm{Pr}_{\mathrm{n}}=9.8 \times 10^{7}, C_{n} \Delta T L_{n}=0.16$

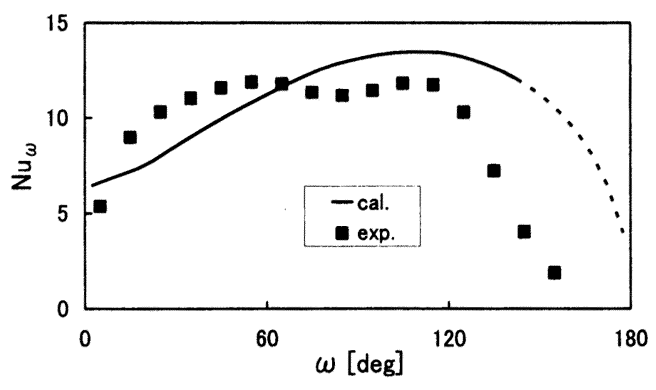

(c) $\mathrm{Gr}_{n} \mathrm{Pr}_{\mathrm{n}}=1.8 \times 10^{7}, C_{n} \Delta T / L_{n}=0.16$

Fig.9 Comparison of experimental local Nusselt number with theoretical one $\left(C_{n} \Delta T L_{n}=0.16\right)$

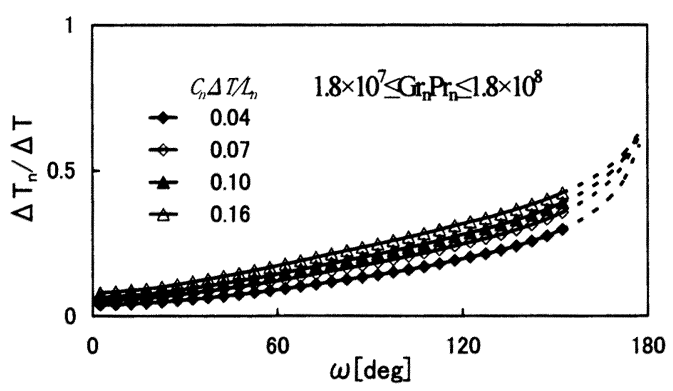

Fig.10 Relationship between temperature drop ratio $\Delta T_{n} \Delta T$ and angle $\omega$ 
すなわち, 試験球表面の全熱抵抗（=ノナデカン液 膜内の熱伝導による熱抵抗十液膜周囲の水の自然対流 による熱抵抗）に占めるノナデカン液膜内の熱伝導に よる熱抵抗の割合を示す. $\left(\Delta T_{n} / \Delta T\right)$ の値は, $C_{n} A T L_{n}$ の值が大きい程大きくなるが, $\mathrm{Gr}_{\mathrm{n}} \cdot \mathrm{Pr}_{\mathrm{n}}$ の値を 変えてもほとんど変化しない．

図 10 から分かるように，ノナデカン液膜の熱抵抗 は,ノナデカン球の下部から上部に向かうにしたがっ て増加しているが，ノナデカン腋膜の熱抵抗と水の自 然対流による熱抵抗との比は, 約 1〜10であり, 水の 自然対流による熱抵抗の方が，ノナデカン液膜の熱抵 抗より大きい，すなわち，式(2)で定義される試験球 周りの熱伝達率はノナデカン液膜表面の水の自然対流 熱伝達率によって大きく影響されることが分かる.

図 8，9 に示すように，水の自然対流熱伝達が支配 的な試験球の下部では，実験值の方が解析值より高い 值となっている. この原因としては, 試験球の上部で ノナデカン夜塊が付着と離脱を繰り返しているため, ノナデカン液膜周囲の水の流れが真球まわりの定常流 れと異なることと, 図 3 に示すように, 実験開始直後 には真球に近い形状であった試験球が時間の経過とと もに洋なし状に変化するため, 液膜周囲の水の流れが 真球まわりの流れと異なり, その結果, 試験球下部に おける水の自然対流局所熱伝達率が真球の場合より高 くなっていることがあげられる.

一方，ノナデカン液膜の熱抵抗が比較的大きい球 上部では解析值の方が実験值より高い值となっている. これは，球状部に付着する液塊の影響によって，ノナ デカン液膜の厚みが液塊近辺で解析モデルより厚くな っているためと考えられる. また，ノナデカン液膜表 面における水の自然対流熱伝達率が真球周りの熱伝達 率と異なっていることも原因として考えられる.

6.4 平均熱伝達率の実臨結果と解析結果 図 11 に平均ヌッセルト数の実験値と解析値の比較を示す.

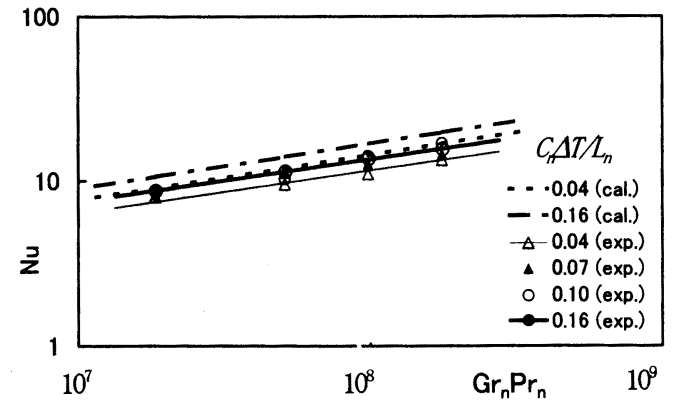

Fig.11 Experimental and analytical average Nusselt number
実験で得られた平均ヌッセルト数は次式(24)で整理 できた. 実験値は式(24)の $12 \%$ 以内に入っている.

$$
\mathrm{Nu}=0.151 \cdot\left(\mathrm{Gr}_{\mathrm{n}} \cdot \mathrm{Pr}_{\mathrm{n}}\right)^{0.257}\left(C_{n} \Delta T L_{n}\right)^{0.117}
$$

解析値は下式て整理できた.

$$
\mathrm{Nu}=0.138 \cdot\left(\mathrm{Gr}_{\mathrm{n}} \cdot \mathrm{Pr}_{\mathrm{n}}\right)^{0.273}\left(C_{n} \Delta T L_{n}\right)^{0.114}
$$

解析値は実験值より大きい。これは, 試験球上部 の局所ヌッセルト数が実験值より解析值の方が大きい ことによるものである. 両者の差は約 $20 \%$ 以下であ り, 実験值と解析值は比較的良く一致していると言え る.

\section{7. 結 敦}

非水溶性物質であるノナデカンの凝固球を水中で融 解させたときの形状変化を観察するとともに，局所熱 伝達率と平均熱伝達率を実験と解析によって調べた. ノナデカン球の直径を $d_{0}=16 \mathrm{~mm} \sim 34 \mathrm{~mm}$ の範囲に変化さ せ, 水温とノナデカン球の温度差を $\Delta T=3.2 \sim$ 13. $2^{\circ} \mathrm{C}$ 範囲に変化させた.これは, $1.8 \times 10^{7} \leqq$ $\mathrm{Gr}_{\mathrm{n}} \cdot \operatorname{Pr}_{n} \leqq 1.8 \times 10^{8}, 0.04 \leqq C_{n} \Delta T / L_{n} \leqq 0.16$ の範用に相当 する. 以下の結論が得られた。

(1)ノナデカン凝固球は融解したノナデカン液の液膜 によって覆われる.ノナデカン球の上部にはノナ デカン液の液塊が形成され，この液塊は分離と形 成を繰り返す.

(2)平均ヌッセルト数の実験值は, $\pm 12 \%$ 以内の誤差 範囲で, 下式で整理できた.

$$
\mathrm{Nu}=0.151 \cdot\left(\mathrm{Gr}_{n} \cdot \mathrm{Pr}_{\mathrm{n}}\right)^{0.257}\left(C_{n} \Delta T L_{n}\right)^{0.117}
$$

解析値と実験值の差は約 $20 \%$ 以下であり, 両者は 比較的良く一致した.

（3）球の下部における局所ヌッセルト数は, 実験值の 方が解析値より高い，これは主として，ノナデカ ン液膜表面の自然対流熱伝達率が真球周りの自然 対流熱伝達率より高いためであると考えられる.

一方, 球上部における局所ヌッセル卜数は解析値 の方が実験值より高い.これは主として, ノナデ カン液膜の厚みが球上部に付着するノナデカン液 塊の影響を受けて，解析値より厚いためであると 考えられる.

\section{新辞}

本研究で用いたノナデカンは株式会社ジャパン エナジ一殿から提供いただいた.ここに記して， 感謝の意を表します. 


\section{文 献}

（1）福迫尚一郎，稲葉秀男，低温環境下の伝熱現象と その応用，(1996)，養賢堂.

(2) Merk, H. J., The Influence of Melting and Anomalous Expansion on the Thermal Convection in Laminar Boundary Layers, Appl. Sci. Res., A-4, (1954), 435-452.

(3) Dumore, J. M, Merk J, and Prins, J. A. Heat Transfer from Water to Ice by Thermal Convection, Nature, 172, (1953), 460-461.

(4) Vanier, C. R and Tien, C., Free Convection Melting of Ice Spheres, AIChE J., 16-1, (1970), 76-82

(5) 福迫尚一郎, 北山邦彦, 田子真, 岡垣理, 海水中 におかれれた水平水円柱の融解熱伝達, 機論, 55514, B (1989), 1678-1985.

（6）稲葉秀男，佐藤㶳二，低凝通点油滴の凝固を利用 した潜熱蓄冷に関する基礎研究（第 1 報），機論 60-580, B (1994), 4236-4243.

(7) Nakao, Y., Hishida, M, Tanaka, G., Shiina, Y., Solidification Characteristics of Rising Immiscible Oil Droplets in Coolant, Int. J. Heat Mass Transfer, 47 (2004), 5339-5349.

（8）山田雅彦, 福迫尚一郎, 小川拓, 疎水性液体中に おける水平水円柱の融解熱伝達, 機論 63-609, B (1997), 1754-1761.

（9）齋藤涁夫，大河誠司，嶋本大祐，過冷却水の熱伝 導率測定の研究，機論 62-594，B (1996), 770-775.

（10）関信弘，蓄熱工学 1 基碄編，(1995), 森北出版.

（11）藤井哲，伝熱工学の進展 3，（1974）91-94，養賢 堂.

(12) Carner, F. H and Hoffman, J. M. Mass Transfer from Single Solid Spheres by Free Convection, A I. Ch E. Journal, 7-1, (1961), 148-152.

(13) Schenkels, F. A. M and Schenk, J., Dissolution of Solid Spheres by Isothermal Free Convection, Chem. Eng. Sci., 24, (1969), 585-593. 